\title{
The Construction of Service-oriented College Student Management Platform Based on "event-driven"
}

\author{
Gao $\mathrm{Lu}$ \\ Education Reform \& Teaching Quality Evaluation \\ Center \\ Bohai University \\ Jinzhou Liaoning \\ 36652078@qq.com
}

\author{
Lin Lin* \\ Education Reform \& Teaching Quality Evaluation \\ Center \\ Bohai University \\ Jinzhou Liaoning \\ linlin3273@163.com
}

\begin{abstract}
The comprehensive reform in the field of education is gradually implemented, and the educational management of students in universities as an essential part of it is in dilemma because of lacking a service-oriented college student management platform which is based on "event-driven". College student management is showing situations of unsmooth information sharing in different departments, such as a low efficiency of management staff, and a limited function in the information transfer due to the defect in the third party communication software .Therefore, colleges and universities are due to expand the development of network and digital services, set up students management platform which is based on "event-driven", and set up a quality assurance mechanism. To form a platform which includes all of the above is good for colleges to pursue their management function to realize the change from control to service, and their management mode from the material-based management to human-based management.
\end{abstract}

Keywords-event-driven; service-oriented college; management of students

College student management is an important part of college management. With the rise of the network era and information technology, traditional college student management cannot meet the need of "People-oriented management", that is, the need for students' self development under the concept of service-oriented college management. It has been clearly pointed out in the Ministry of Education's "Plan for ten-year development of Educational Information (2011-2020)" that "vigorously promote the construction of digital campus for normal colleges, improved digital platform for issuing information, network teaching, management services and on-campus cultural life as well as system integration and data sharing" [1] In this context, it is the requirement of the big data era and service-oriented colleges for student management to construct a service-oriented college student management and information platform based on "event driven" and it is also a effective strategy for colleges to positively face challenges to student management in the new situation.

\begin{abstract}
I. GOAL, BASIS AND TOOL: RESEARCHES INTO SERVICE-ORIENTED COLLEGES AND ST UDENT EDUCATION MANAGEMENT PLATFORM BASED ON "EVENT-DRIVEN"

Currently, China's education field has already entered onto a new stage - stage of comprehensive management, and the field of higher education's student management is no exception. It is necessary and urgent to establish modern education governance system and improve internal governance structure of schools [2]. In order to carry out student management activities and realize "education for the people" education and management functional activities, colleges must update their management concept and change management model to seek the integration of student education's management objectives, basis and management tools. While in order to achieve this integration, we must first clarify the goal, basis and tool for college student education management.
\end{abstract}

\section{A. Service-oriented Management is the Objective of College Student Management}

"Service-oriented colleges" has evolved from the concept of "service-oriented government" and is opposite to "control-oriented colleges", which usually start from self-control and the convenience of management while colleges' leading designers play a leading role in student management. It is the mandatory and unilateral practice of college managers as what services to be provided to teachers and students and how these services are provided without considering students' own will and diversified demands. There is a "command-obedience" relation between college managers and students because students can not be subject to the will of managers, but service-oriented colleges are those colleges serving for students, taking serving for students as the theme for colleges to exist and development, and colleges are running guided by the "people-oriented management" concept.

In terms of the current operation way of college student management system, it can be realized mainly through vertical linear management with a lack of effective multidimensional and multilayer interaction. Prominent 
features of this management system are top-to-bottom order, direction, scheduling and control of student managers, that is, students obey and receive managers' orders. Student managers at colleges have always been serving as the supreme "commander", which is not conducive to reflect the function of services in student management [3]. It is just due to the reflection of emphasizing administrative service but not college students, the object of administrative services that college student management has yet not reflected the "people-oriented education" value of promoting the growth of students with a lack of analyzing college student management from people's nature and promoting the concept of "people-oriented" management and "management for people" from the basic condition of human nature. "Management for people" is one of the main differences between higher educational management and management of other social organizations. Therefore, college student management should reflect that the core of "educating people as the basis" is to change the management mode from the "cost-oriented management" concept to the service-oriented student management with "people-oriented management" as the goal.

\section{B. "Event-driven" is the basis for Colleges to Realize the Function of Student Management}

At present, material management or institutional management (also called hard management) is the most common in college student management. That started from transactional management requirements, emphasizing control over students, one size fits all standard requirements of students. It is confined to transaction management, lack of concern for students' individual needs, ignoring the cultivation of the students' personality, enthusiasm and creativity. Lack of students as the most important resource in colleges and universities, student ability, talent, interest, psychological science, such as providing the most suitable service and management, and fully taking into account student growth in the management process of "people management".

"Event-driven" is a strategic decision of continuity in management. In order to prevent the accumulation of time following the events of the current point in time, to mobilize available resources, solve emerging problems in the shortest amount of time, in the areas of public management, computer programming, economics is used. In the information age "event" is defined as a computer system for automatic processing of information filtering as a standard, the system can be automatically processed and filtered for "regular event", instead of "unexpected events".

"Event drive" to on event of sensitive and reaction, reaction real-time thinking of "event drive" concept completely can became upgrade University students education management level of a new thought, in other words, University to achieved itself students management to service type University of change, based on "event drive" is its based, not based on event drive, but still of "sector drive", students education management activities still will stay in procrastination rambling of old has State. University students management of "event drive" refers to that to prevent students management affairs stacked, improve students management efficiency, timely followed current time points occurred of event, using all can mobilization of resources, strengthening university management process in the of overall, and rates, and active of information passed, in University system within rates report important event, makes teachers and students, and admin is trative personnel bottom produced quickly, and has creative of response, with shortest of time solution students learning and life in the constantly appeared of problem.

\section{C. “Even-driven” Student Management Platform is a Necessary Tool for Current Service-oriented College Student Management}

On Amazon and Dangdang, people can browse a book or browse what other books, and according to the records of consumers search for books recommended to books of interest to searchers, and Google, Baidu search for records based on the users most want to see contents of the row at the top. [4] These sites and search engines than consumers, the search itself understand the preferences of its own, because of today's society, an age of mass production, sharing and use of data is opened. Based on the data unit, based on the cloud computing means of information storage, sharing, and mining, have a cheap and effective way to the large terminal data, high speed, storage, and analys is and calculation at any time. [5] This gives college students ' learning and life revolutionary and disruptive change. With the rise of mobile Internet and Smartphones as well as iPad, the popularity of mobile devices, such as college students get used to the way client Internet access through application, access to information and knowledge. The network era and the rise of information technology student management in colleges and universities is suffering the same challenge and excitement. Under the background of mass higher education, enrollment growth in student numbers at the same time, most college student counselor ratio imbalance, resulting in student management work "Instructor live" situation. Simple and labor-intensive "human interaction" type of "student guide" students ' management has been unable to meet large data on students ' management in the era of cloud computing's "interactive" requirement. Big data brings to the education "one of the most important changes is that it makes the education management and more personalized service. United States, Colorado is the use of "big data" systems to improve the State's educational management and services ${ }^{1}$. Student management in colleges and universities must adapt to the requirements of the age of big data, students through network platform and collaborative management of the information network.

Based on the above analysis, service-oriented management is the management of college students to achieve the goals, based on event-driven is the Foundation of student management in colleges and universities, student management information platform is the age of big data service-oriented college students the necessary tools to manage these three complementary and synergistic effects. Only based on "event-driven" service-management 
platform for college students, College "educating people through service" concept can be realized.

\section{REALITY AND DILEMMA: COLLEGE STUDENT} MANAGEMENT IN CHINA IS TRAPPED IN A DILEMMA DUE TO THE LACK OF STUDENT MANAGEMENT PLATFORM

All management activities in colleges related to student educational management has fallen into a dilemma due to the lack of "event-driven" service-oriented college student management platform.

\section{A. Unsmooth Information Sharing among Student Management Departments}

Management of student management in colleges and universities, including many activities: student enrollment management, student internships and employment management, educational management, care management, activity management, logistics management, healthcare management, practice management, from students upon admission to graduate student employment, through learning the whole process of life. A large number of structured and unstructured data are associated with these management activities arising from the daily work, stored as folders or documents. Over time that these data be islands of information, not conducive to staff and students queries and use the system.

At present, experimented with the many colleges and universities student management network management platform, but most rely on network management platform in colleges and universities is limited to students ' information management system includes a subsystem, such as Oxford University course management system, file-sharing systems, Tsinghua University, Penn State University comprehensive educational system. Various subsystems function than a single, stand-alone, in the format of the information, the output of which a lack of uniformity in the way. Few colleges and universities from the height of the whole, according to the logic design of student management system across sectors, due to lack of unifying the different subsystems within the information management platform brings together students, student management present situation of sharing and circulation of information presented is not smooth.

\section{B. Low Efficiency of Student Management Personnel Due to the Lack of a Platform}

Management of college students today, especially school counselors are a huge number, but you want to repeat for each different student distribution with repetitive message mostly. A case study of a student employment information statistics, College Internship employment at the appropriate time each year to distribute the forms to undertake the task of training college students ' counselor, college counselor and then distribute it to fresh graduates, similar mechanically repeating every year. Student encounter any problems, must rely on student Management Department can only be resolved with other students. Counselors work with each student Management Department presents a false busy scene, but inefficient management due to a lack of student management platform. Peking University campus information portal application systems including courses, teaching, management, pers onnel, Office, SMS platforms, such as finance, training of the party school, based on this information portal, student counselor's role can be replaced by a computer network, then students will and management demands are express and resolve in a timely manner.

\section{Information Transmission Function Relying on the Third Party's Communication Software is Limited}

Most of the management of college students by student instructors ' relying on QQ groups, app group, fetion, mobile communication and social networking software of third parties, mainly through mail attachments with social software, complete the upload is sued between students and the students' management work. This relies on third party communications software of information convey while by students counselor belongs II level College of limit, the community range only Council limited to a College of a class or a professional their groups, information passed function by limited; on the, through mail and social software transfer of file in size and upload speed Shang by third party of limit effect factors larger, the management sector and counselor just relies on this way of information transfer, both increased has students Counselor of workload, And prevented direct communication between student and student management. Student instructors and students management as long as either negligence or neglect, is likely the result of human factors missing students or their parents need dealing with tasks of data requests in a timely manner, which delayed progress of student management work. On April 10, 2015, Tianjin Normal University student committed suicide by burning charcoal before their mother has commissioned by means of third-party address their instructor to student dormitories look about, students have found the counselors people restore their mother did not see suicidal students, eventually students missed the best time for rescue.

Departments of student management of colleges and universities, student counselors and faculty and students of students lacking one to create the information-sharing and communication platform, or, the students of the University management activities into a bottleneck due to lack of student management platform.

\section{TREATMENT METHODS: CONSTRUCT “EVENT-DRIVEN" SERVICE-ORIENTED COLLEGE STUDENT MANAGEMENT PLATFORM}

Interagency information sharing of student management in colleges and universities is not smooth, student managers for lack of platform management inefficiencies and rely on third-party the information transmission function of communications software limited is sues can be based on "event-driven" service-management platform for college students to be effectively resolved. University students management of platform can has variety form, but building based on "event drive" of service type University students management platform is in digital campus based Shang building of a set information released, and information shared, and management service and campus culture life service, for 
one of digital platform, can fast effective of solution University in students management process in the encountered of "General event" and "accident event". By automating the routine work of student management in colleges and universities more efficient, by "accident", access to universities outside of the special information, enable students to encounter problems in the shortest possible period of time to be the most effective solution, adjust for the top-level design of student management in colleges and universities, management optimization provides an opportunity, so we see it as the most effective student management platform.

\section{A. Expand College Network and Digital Services}

For today's colleges and universities, the network and the construction of digital campus not only has become indispensable to measure the level of a school management services essential, is becoming a new symbol of modernization of University Management service level. [6] The network and the development of digital services have become key elements of promoting University Management service standards. Digital campus services to traditional life based on teaching, research and management services and activities, but compared with traditional services, rich in content and development function has incomparable superiority. Campus application system to mobile phones and the Internet, for example, mass groups receive functions, breaking the traditional relies on third-party address software clients that send messages narrow limits. Modern means of service time and space of barriers can also improve the efficiency of college student management services to an unprecedented height. In addition, data networks and digital services can be in the background of the student's search data search to understand the students 'individual requirements to avoid compulsory service, and an effective two-way communication channels.

By extending the function of the campus network and digital service, to achieve a "teaching of information dissemination, networking, knowledge-sharing, management services, and campus life services" effective, and propulsion systems integration and data sharing of students ' management in the process of "regular event" settlement process announced that rapid and effective solution in favor of regular events. For distinct positive events in universities and colleges, for example, schools in some areas significant results, image's reputation spread in schools, students ' advanced characters, through expanded digital services, timely and effective promotion. For example, on February 5, 2015, Bohai University Arts and media college student double return fire rescue's story through a friend, campus services, inside and outside the school gained a reputation and donations received in a short time a hundred thousand of. Expand networks and digital services, and internal groups of college students can play in encouraging and morale. External lift to the University's own image, developing student internships, job market. Threats or potential threats to the survival and development of University events, internal and external emergencies, students in colleges and universities within the emergent conflicts, in digital service in the fast processing speed, real-time results to similar incidents the students guidance, driving the situation to a good direction.

\section{B. Set "Event Driven" Student Educational Management Platform Based on Digital Services}

Data alone are not enough, now, for data analysis, and data mining is power, [7] on the student management in colleges and universities, the key is to find the data implied law and enlightenment. How in information of provides party--that among university management institutions and teachers, and students by need distribution and aggregate perception information, and based on university environment by occurred of changes, dynamic of, and real-time collaborative related sector of service or service process made fast reaction, makes teachers or students encountered of event or problem in shortest of time get solution, is construction based on "event drive" of service type University students education management information platform to solution of core problem.

Functions the universities through the adjustment, the pursuit of management functions shift from regulation management to service management, management from the management to the people-oriented management transition, encourage and support students' self-management. Extend digital services on the basis of established the appropriate event response mechanism, to enable real-time, rapid response to all types of events occur, and event-driven development targeted to promote the rapid increase of level of education management in College [8].

Students rely on their dig ital campus network and the client's account and login password, access to student management platform to solve the problem. Successfully run public management platform has a lot of event-driven type, for example, national public opinion focused on people's livelihood, the first Smartphone-Dalian public information platform of mobile phone clients. Want to consult, there are complaints, recommendations, check feedback of users as long as the public network can "to resolve the problem." ${ }^{2}$

Student education and management platform based on event-driven plates Fig. 1, Fig. 2 shows: first, the students via the Web or mobile APP log management platform, selecting the events to be solved according to their respective. Such as course, practical training and employment and life services, scholarships and certificates information, learning activities, collection of fees, security, apartment, diet, mental health, and event type, and then, into related issues list section, this section lists all types of students have been consulted and resolved issues and strategies, students can search by keyword to find the answer. If it is not in the list of students to solve the answers, students can be briefly described the event to solve, the system automatically adds the student to solve the event workers assigned to a job-related duties as resolved. Students wait for results after the release of results, grade students to evaluate the outcome of this incident. When the select event plates, students may also choose services through related to artificial problems, 
students reflect the problems by artificial service personnel be as signed to the appropriate Department.

\section{Construct Event-driven Service-Oriented College Student Management Platform Quality Guarantee Mechanism}

Students are assigned to each sector need to be addressed within the scope of work submitted in time, the department must give a reply within half an hour, and timely disclosure of problem-solving progress; for the holidays in question submitted, it is necessary at the end of the holiday The first working day to respond. Form an effective quality assurance mechanisms for student management platform services, for individuals with a low student evaluation many times accordingly punished. Such quality assurance mechanisms to avoid student management department staff member with the guide and other human factors have led to sluggish student management have a significant effect, even student counselor positions may be substituted with a computer system.

Bohai University in comprehensive reform of the education system in an innovative way to cancel student counselor system, the establishment of student development with the Centre and university students' safety and life service center, two students managed to work one-stop services, and the establishment of "I want to adjust sleep" "I want to repair," "I want to appeal," "leaving the record" and other event-driven design student management sector. On the basis of expanding digital capabilities on Bo large, Bohai University-based event-driven service-oriented management platform for college students in a student-centered educational philos ophy and the convenience of students, the purpose of student services, student work content set to handle daily affairs, development consulting and guidance services, campus culture and spirit construction in one, sought through convenient, professional and efficient service to promote the development and realization of the goal of excellence in education schools, the platform is currently in the commissioning phase.

Combined "event drive" schema and "oriented service" schema of design thought and construction of based on event drive of service type University students education management platform integrated has students user domain, and university students management information space domain and physical space domain, achieved has "students-computer network-management information" of dynamic collaborative, can convenient to support students management information of by needed distribution and aggregate, and achieved event drive of across business, and across sector of service dynamic collaborative, is University achieved efficient of service type students management of trend by needed.

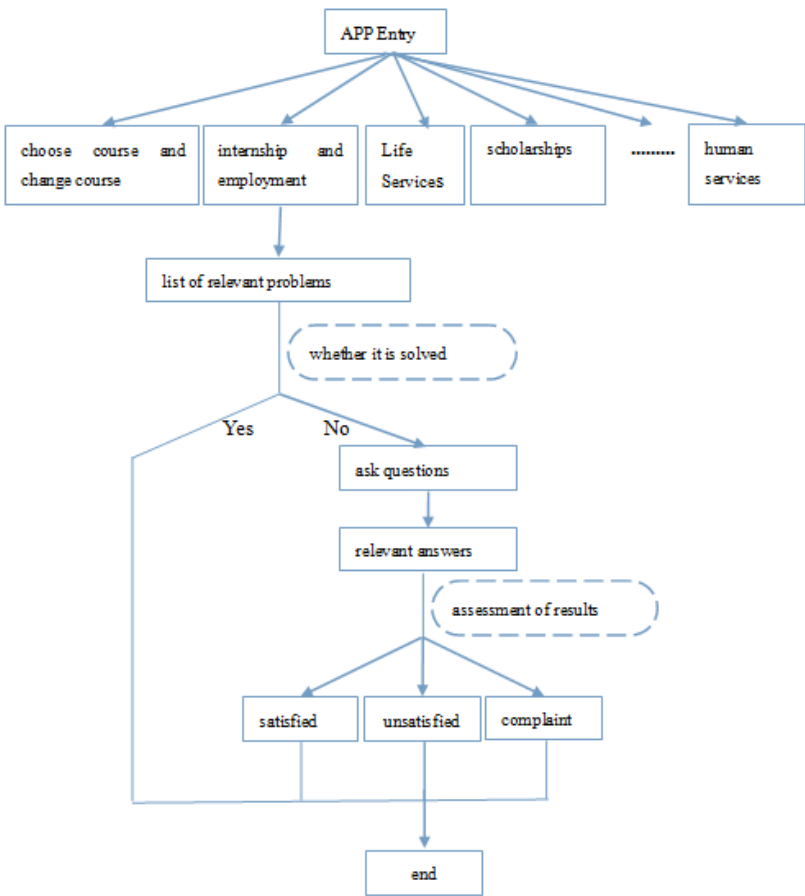

Figure 1. Diagram of College Student Management Platform's Students End

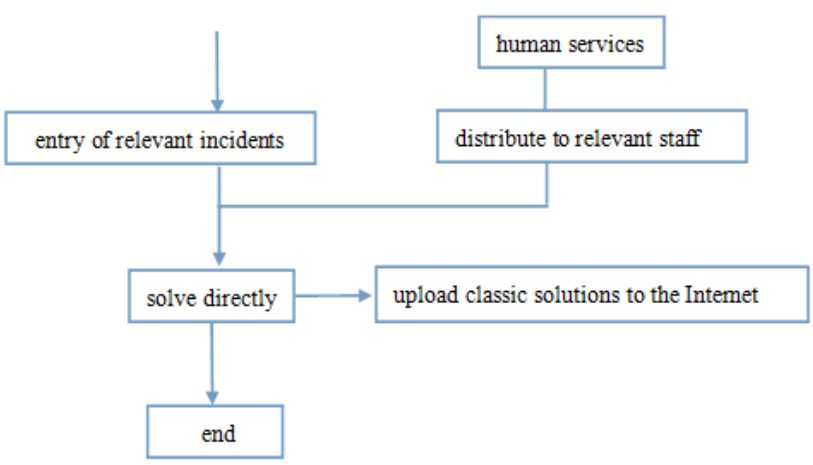

Figure 2. Processing Diagram of College Student Management Platform

\section{ACKNOWLEDGMENT}

Fund project: general project of 2014 national social science fund "res earch into ecological treatment theories of China's higher education during one-way competition period" (14BGL105), general project of Liaoning educational science "the 12th five year plan" "res earch into academic influence of Liaoning educational research institutes" (JG15DB034), one of the periodic results of the 1st Liaoning educational evaluation association's research into teaching reform and teaching quality assessment "research into academic influence of Liaoning educational research institutes and strategies for improvement" (PJHYYB15199); one of the periodic results of 2015 general project "research into path for local colleges to improve social service function" held by Jinzhou Association of Social Science.

\section{REFERENCES}

[1] Ministry of Education, the People's Republic of China. "Plan for Ten Years' Development of Educational Information (2011-2020)"'[Z]. 
[2] Shi Zhongying. Pursuing the Value of Educational Treatment [N]. Journal of China's Education, 2015-4-30 (06).

[3] Tian Jie. Innovation of College Student Management Work [J]. Education \& Career. 2015, (02):45-46.

[4] [British] Ian•Aris. Big Data Thinking and Decision-Making [M]. Translated by Gong Xiangzhan. Beijing: People's Posts and Telecommunications Publishing House, 2014:02.

[5] [British]Victor $\bullet$ Mayer-Schoenberg,Kenneth $\bullet$ Cukier. ransformation of Life, Work and Thoughts in the Big Data Time [M]. Translated by Zhou T ao, etc. Zhejiang People's Press, 2013:13.

[6] Wang Tingzhi, Ding Xiaoyan. Utility Development of "Even Driven" in College Student Educational Management [J]. Modern Educational Management. 2009, (12): 70-72.

[7] [U.S.A.] David•Feinleib. Cloud Map of Big Data: How to Seek the Next Opportunity in the Big Data Time [M]. Translated by Sheng T angyan. Hangzhou: Zhejiang People's Press, 2014:02.

[8] Xiong Mian. Characteristics of College Service Management during the Time [J]. Exploration of Higher Education, 2020(06):43-45.

1 In 2009, the Colorado education authority began to implement the Relevant Information to Strengthen Education (RISE in short) to collect all information about students, teachers and the school so as to help schools to improve teaching and students to obtain academic success.

2 Dalian residents Web page and mobile synchronization with version information, Mobile Home principal shows a variety of public information, users can be provided by section of navigation buttons, build, write comments, help, and can quickly browse the network of public opinions message or use the keyword search function to quickly find public Web content they are interested in. From the opening in 2011, by 2014, Dalian public network has received the public message of 53,000 , publishing information and news for the convenience more than 10,000 articles, website traffic more than 11 million visitors, message reply is $98.8 \%$ the public satisfaction rate of $93.8 \%$, municipal masses has become a regular, common platform. Gaining recognition by the masses because the platform can really do solid work for masses and solve practical problems. Public opinion NET do well there is only one standard, "is to have adhered to and do practical things for the masses, the masses recognized not recognized. Attitudes towards public networks of the various departments, the departments deal with people's attitudes, attitudes toward work. "The above figures and text from the sky and health network. 